\title{
SINERGISITAS KEBIJAKAN DAN STRATEGI PENCEGAHAN TINDAK PIDANA TERORISME DI PROVINSI BALI
}

\author{
I Made Walesa Putra \\ I Gst Agung Ayu Dike Widhiyaastuti \\ Universitas Udayana \\ Email:mdwalesaputra@yahoo.com
}

\section{ABSTRACT}

The Writing of "The Synergicities of Policies and Strategies of Prevention Terrorism's Crime of Bali Province" are aimed to develop legal science in general and particular in the field of criminal's law as well as knowing and studying the synergy between roles and strategies from the government, law enforcers and the community and to find, to analyze, to review and to provide legal solutions to obstacles in the effort to prevent terrorism in crime of Bali Province so it can be constructed to be an effective counter measures formulation.

The method used in the achievement of the goal is approach Juridical Empirical method, namely legal research with facts approach by observation and in-depth interviews on object of research.

The research was conducted on Bali Police, Kesbangpolinmas Bali, FKPT, FKUB, MUDP, and Religious figures in Bali. The results disclosed that each agency/organization / institution / individual has carried out the obligations according their tasks effectively and strive synergize the policies and strategies of prevention in terrorism. There are a few obstacles ranging from funding, facilities, quality-quantity of human resources to the constraints associated with legislation. By identifying several issues and to find the best solution for more effective prevention of acts of terrorism in synergy and sustainable.

Keywords: Synergicities, Policies, Strategies, Prevention of Terrorism

\section{PENDAHULUAN}

Bagaikan dua sisi mata uang, globalisasi tidak hanya memberikan sisi keuntungan yaitu kemudahan komunikasi, teknologi, informasi (real time) lintas negara, disamping juga berdampak negatif. Sulit disangkal bahwa di era globalisasi justru tindak pidana terorisme tumbuh dan berkembang.

Sejumlah aksi terorisme menunjukkan mata rantai antara kelompok dari dalam dan luar negeri. Seperti Al-Qaeda, Jamaah Islamiyah dan kelompok Abu Sayyaf, hingga akhir-akhir ini muncul kelompok ISIS.

Provinsi Bali, etalase Indonesia bidang pariwisata, sangat dikenal mancanegara, setiap tahun jutaan turis berlibur ke Pulau Seribu Pura ini. Kejadian Bom Bali I di Kawasan Legian-Kuta, 12 Oktober 2002, menewaskan 202 jiwa serta peristiwa Bom Bali II, 1 Oktober 2005, menelan korban 22 orang meninggal dunia (Abdul Wahid, dkk, 2004:2), peristiwa yang pernah meluluhlantakan pariwisata Bali.

Kejahatan terorisme tergolong Extra Ordinary Crime karena dilakukan dengan aksi kekerasan, tak berprikemanusian, merupakan pelanggaran HAM berat, justru kebanyakan korban adalah mereka yang tidak bersalah, sehingga diperlukan upaya luar biasa penanggulangannya.

Beberapa waktu lalu, kembali terjadi aksi terorisme baik di dunia internasional salah satunya 
di Perancis, dan nasional yaitu terakhir serangan di Plaza Sarinah-Jakarta, 14 Januari 2016, menewaskan sedikitnya 8 orang (https:// id.wikipedia.org/ Serangan Jakarta 2016, diakses 16 januari 2016). Bahkan ancaman selanjutnya aksi teror terinspirasi menggunakan racun sianida (http://www.merdeka.com/peristiwa/ , Biasa ngebom, mungkinkan teroris teror polisi dengan racun sianida?, diakses 20 februari 2016.).

Tentunya Indonesia/Bali tidak ingin kecolongan peristiwa Bom Bali terulang. Kebijakan dan strategi pencegahan yang tepat, upaya terbaik penanggulangan aksi ini. Pepatah menyebutkan "mencegah lebih baik dari mengobati", menghindari kerugian dan jatuhnya korban. Namun upaya ini harus ada sinergi antara pemerintah, aparat penegak hukum dan masyarakat agar lebih efektif, dalam rangka tegaknya Negara Kesatuan Republik Indonesia (NKRI) serta keamanan daerah wisata Bali khususnya, secara komprehensif dan integral.

Dalam Pasal 1 Perpu No 01 Tahun 2002 tentang Pemberantasan Tindak Pidana Terorisme (sekarang sudah disahkan menjadi UU No 15 Tahun 2003 tentang Pemberantasan Tindak Pidana Terorisme), bahwa terorisme adalah perbuatan melawan hukum secara sistematis dengan maksud untuk menghancurkan kedaulatan bangsa dan negara dengan membahayakan bagi badan, nyawa, moral, harta benda dan kemerdekaan orang atau menimbulkan kerusakan umum atau suasana teror atau rasa takut terhadap orang secara meluas, sehingga terjadi kehancuran terhadap objek-objek vital yang strategis, kebutuhan pokok rakyat, lingkungan hidup, moral, peradaban, rahasia negara, kebudayaan, pendidikan, perekonomian, teknologi, perindustrian, fasilitas umum, atau fasilitas internasional.

Dengan demikian, upaya penanggulangan kejahatan secara garis besar dapat dibagi dua, yaitu lewat jalur penal (hukum pidana) dan jalur non penal (bukan/di luar hukum pidana). Dalam pembagian G.P. Hoefnagels diatas, upaya-upaya yang disebut dalam butir b) dan c) dapat dimasukkan dalam kelompok upaya non penal.
Dibedakan bahwa upaya penanggulangan kejahatan lewatjalur "penal" lebih menitikberatkan pada sifat represif (penindasan / pemberantasan / penumpasan) sesudah kejahatan terjadi sedangkan jalur "nonpenal" lebih menitikberatkan pada sifat preventif(pencegahan/penangkalan/pengendalian) sebelum kejahatan terjadi. Dikatakan sebagai perbedaan secara kasar, karena tindakan represif pada hakikatnya juga dapat dilihat sebagai tindakan preventif dalam arti luas (Barda Nawawi Arif, 2010:42).

Terdapat tujuan penulisan, yaitu:

1. Untuk mengetahui bagaimana peran dan strategi pemerintah, dan aparat penegak hukum (diantaranya Polisi, TNI) serta masyarakat (termasuk tokoh masyarakat, tokoh agama, pencalang, dll) dalam pencegahan kejahatan terorisme di Provinsi Bali.

2. Untuk menemukan, menganalisis, dan mengkaji serta memberikan solusi hukum terhadap kendala-kendala/hambatan-hambatan dalam upaya pencegahan kejahatan terorisme di Provinsi Bali.

3. Mengetahui dan mengkaji sinergisitas pemerintah dan aparat penegak hukum, serta masyarakat (termasuk tokoh masyarakat, tokoh agama, pencalang, dll) sehingga dapat dikonstruksikan formulasi sinergisitas yang efektif dalam pencegahan kejahatan terorisme di Provinsi Bali.

\section{METODE PENELITIAN}

Untuk memperoleh suatu pembahasan sesuai dengan apa yang terdapat di dalam tujuan penyusunan bahan analisis, maka dalam penulisan penelitian ini menggunakan metode pendekatan secara Yuridis Empiris, yaitu penelitian hukum dengan cara pendekatan fakta yang ada dengan jalan mengadakan pengamatan dan penelitian dilapangan kemudian dikaji dan ditelaah berdasarkan peraturan perundang-undangan yang terkait sebagai acuan untuk memecahkan masalah, dalam hal ini pendekatan tersebut digunakan untuk menganalisis secara kualitatif (Rony Hanitijo Soemitro, 1998:52).

Pendekatan yuridis empiris yaitu suatu pendekatan yang dilakukan untuk menganalisis 
tentang sejauh mana suatu peraturan atau perundang-undangan atau hukum berlaku secara efektif dalam masyarakat (Kuntjaraningrat, 1999:20), yaitu terkait Pencegahan Tindak Pidana Terorisme di Provinsi Bali.

\section{HASIL DAN PEMBAHASAN PERAN DAN STRATEGI PEMERINTAH, APARAT PENEGAK HUKUM, TOKOH MASYARAKAT DAN AGAMA DALAM P E N C E G A H A N K E J A H A T A N TERORISME DI PROVINSI BALI}

\section{Kepolisian Daerah Provinsi Bali (Polda Bali)}

Unit Anti Teror di Kepolisian Daerah Bali merupakan salah satu bidang dari Direktorat Reserse Kriminal Umum (Dit Reskrimum). Upaya Preventif yang dilakukan Polda Bali adalah pertama Mapping daerah-daerah rawan, dimulai pintu masuk Bali yaitu daerah yang mungkin dilewati, kemudian yang diduga menjadi tempat tinggal. Jalur-jalur tikus masuk Bali seperti di daerah Klungkung melalui jalur pantai antara lain pelabuhan rakyat dan jalur lainnya di sepanjang pantai yang ada di daratan Klungkung, Nusa Penida, serta Lembongan. Pemeriksaan ketat di pelabuhan rakyat di Klungkung yaitu Tri Buana, Pelabuhan rakyat Kusamba dan Pesinggahan. Sedangkan pelabuhan rakyat di Nusa Penida difokuskan di wilayah Buyuk, Toya Pakeh, Sampalan, Mentigi, serta pelabuhan Lembongan. Sedangkan di Karangasem dilakukan oleh Polres Karangasem memperketat pengawasan di kawasan Pelabuhan Padangbai, juga fokus di pelabuhan tradisional khususnya Polsek Kubu, Abang, Manggis dan Kota Karangasem. Serta tentunya pengamanan terutama di kawasan Pelabuhan Gilimanuk dan pelabuhan-pelabuhan tradisional di sekitarnya di daerah pesisir Kabupaten Jembrana.

Kerjasama dilakukan dengan tokoh-tokoh masyarakat dengan cara unit akan turun ke wilayah untuk melakukan pengarahan deteksi dini dan cegah dini kepada masyarakat termasuk juga kepada tokoh agama, Bintara Pembinaan dan Keamanan Ketertiban Masyarakat
(Babinkamtibnas), dan Kepolisian Resor (Polres), serta Kepolisian Air (Polair). Pengarahan tersebut diberikan sebagai upaya Polda Bali melakukan pencegahan bersinergi antara penegak hukum dan masyarakat, mengingat juga tim anti teror yang dimiliki Polda Bali terbatas jumlah personilnya, hanya beberapa orang saja. Pemberdayaan masyarakat untuk membantu upaya pencegahan sebagai contoh peran kelompok nelayan sangat penting jika mengetahui ada kecurigaan terhadap pihak asing yang datang di daerah mereka, kelompok nelayan sangat menguasai medan atau wilayah mereka yang juga sebagai sumber mata pencaharian, diharapkan mereka melapor dalam hal ada kecurigaan tersebut.

Sehubungan dengan bahaya laten dari Teroris, di Bali saat ini ada 'sel-sel' yang dapat berpotensi sebagai teroris namun tergolong sel mati artinya tidak membahayakan. Sekalipun demikian, Polda tetap melakukan pengawasan ketat bahkan sel-sel tersebut di-pressing atau ditekan hingga potensi itu hilang. Sel-sel mati tersebut antara lain mereka yang diduga dapat saja menyebarkan ajaran-ajaran radikal berdasarkan ketokohannya misalnya melalui agama, hal tersebut telah diketahui aparat/intelijen dan diawasi terus. Sedangkan selsel teroris yang tergolong hidup justru diduga di luar Wilayah Bali seperti di Bima (Nusa Tenggara Barat), Jawa Timur, Jawa Tengah, dan Sulawesi Tenggara.

Informasi dari masyarakat juga dirasakan perlu oleh Polda Bali sebagai upaya pencegahan, sekalipun ada kendala terkait peraturan perundang-undangan yang ada yaitu UU No 15 Tahun 2003 tentang Pemberantasan Tindak Pidana Terorisme terkait dengan pelaku yang baru melakukan perencanaan teror belum dapat dijerat hukum, harus telah ada kegiatan pelaksanaan baru dapat dipidana, hal ini juga sebagai kesulitan kepolisian untuk menangkap sel-sel yang berpotensi sebab telah diketahui gerak-geriknya namun belum dapat dilakukan tindakan.

Kepolisian Bali juga bekerjasama dengan Tentara Nasional Indonesia (TNI), ditambah Aparat Desa berdasarkan keterangan dari Komunitas Intelejen Daerah (Kominda), melaksanakan kegiatan razia penduduk pendatang 
secara terjadwal atau berkala, serta juga sewaktuwaktu jika diperlukan.

Sementara keterkaitan juga dengan lembaga lainnya yaitu Forum Kerukunan Umat Beragama (FKUB), Majelis Utama Desa Pakraman (MUDP), Badan Kesatuan Bangsa, Politik dan Perlindungan Masyarakat (Kesbangpolinmas) Bali serta dengan Badan Nasional Penanggulangan Terorisme (BNPT)/Forum Komunikasi Penanggulangan Terorisme/FKPT (sebagai Cabang BNPT di Daerah), Polda selalu berkoordinasi Intensif dalam hal pencegahan bahkan pemberantasan terorisme, sampai dengan upaya deradikalisasi dari pelaku agar tidak kembali sebagai teroris seperti upaya yang dikembangkan dengan BNPT/FKPT.

Secara khusus pencegahan dalam hal kontra radikalisme yang dilakukan dengan deradikalisme juga dilakukan Polda Bali di mengandeng Tokoh masyarakat, Tokoh Agama serta Departemen Agama. Bahkan strategi pencegahan juga dilakukan oleh Polda Bali dengan membentuk Tim Media Sosial (Medsos) sebagai upaya pencegahan di bidang teknologi informasi yaitu memutus jaringan terorisme dan mendeteksi kegiatan serta keberadaan pelaku. Namun ada kendala juga yang dihadapi antara lain dikarenakan terlalu banyak website yang beredar sehingga kesulitan untuk memeriksa secara menyeluruh, selain juga belum ada kerjasama dengan operator mengakibatkan akses tim medsos sangat terbatas.Dan baru-baru ini Polda Bali juga membantu korban bom Bali I dan II dengan mengeluarkan Surat Keterangan Sebagai Korban Teroris pada peristiwa tersebut sebagai upaya pengajuan kompensasi melalui Lembaga Perlindungan Saksi dan Korban (LPSK).

\section{Badan Kesatuan Bangsa, Politik, dan Perlindungan Masyarakat (Kesbangpolinmas) Provinsi Bali}

Badan Kesatuan Bangsa, Politik, dan Perlindungan Masyarakat (Kesbangpolinmas) memiliki 3 bidang yaitu:

- Bidang I Kewaspadaan dini/kewaspadaan daerah

- Bidang II Politik dan negara
- Bidang III Ketahanan masyarakat/wawasan kebangsaan.

Dengan visi yaitu terwujudnya masyarakat Bali aman, tertib, dan harmonis, sedangkan misi antara lain; memanfaatkan stabilitas politik, dalam rangka ketahanan sosial budaya yang dinamis dan kondusif, meningkatkan kenyamanan masyarakat serta mewujudkan sistem pengamanan yang berstandar Internasional. Dalam hal ini membantu Gubernur dalam penyelenggaraan pemerintahan dibidang kesatuan bangsa, Politik dan perlindungan masyarakat. Tujuannya adalah meningkatkan rasa aman dan tenteram bagi masyarakat serta memperkuat ketahanan sosial politik dan keamanan. Kesbangpolimas melakukan koordinasi dengan instansi terkait, berperan dalam mengumpulkan informasi yang sifatnya koordinatif terkait dengan perencanaan dan koordinasi.

Berkaitan dengan visi, misi serta maksud tujuan dari Kesbangpol dalam hal keamanan masyarakat juga berkaitan dari ancaman bahaya terorisme. Untuk mencegah bahaya ancaman terorisme langkah Kesbangpol diantaranya membentuk Forum Kewaspadaan Dini Masyarakat (FKDM) yang bertugas antara lain:

a) Menjaring, menampung, mengkoordinasikan, dan mengkomunikasikan data dan informasi dari masyarakat mengenai potensi ancaman keamanan, gejala atau peristiwa bencana dalam rangka upaya pencegahan dan penanggulangannya secara dini;

b) Melakukan koordinasi dan konsultasi pengamanan lintas fungsi dan institusi dalam rangka membina semua potensi keamanan, ketentraman, dan ketertiban masyarakat;

c) Melakukan rapat-rapat untuk memberikan rekomendasi sebagai bahan pertimbangan bagi Gubernur mengenai kebijakan yang berkaitan dengan kewaspadaan dini masyarakat; dan

d) Melaporkan hasil kegiatan kepada Gubernur melalui Wakil Gubernur.

FKDM terdiri dari Dewan Penasehat dan Pengurus, Dewan Penasehat diketuai oleh Wakil Gubernur Bali, dan sebagai sekertaris adalah Kepala Kesbang, serta beranggotakan dari perwakilan berbagai lembaga antara lain; 
Wakapolda Bali, Kepala Badan Intelijen Daearah Bali, Komandan Korem 163/Wira Satya, Komandan pangkalan TNI Angkatan Laut Denpasar, Komandan pangkalan TNIAngkatan Udara I Gusti Ngurah Rai, Kepala Kantor Wilayah Kementrian Hukum dan HAM Bali serta Kepala Pelaksana Harian Badan Penanggulangan Bencana Daerah Provinsi Bali.

Pengurus FKDM juga terdiri dari berbagai unsur dalam masyarakat yaitu; Tokoh masyarakat, Majelis Utama Desa Pakraman, Tokoh Agama, Praktisi hukum/Akademisi, unsur Pemuda/OKP, unsur Pemuda/PMI.

Forum kewaspadaan diri terhadap provinsi, desa, kelurahan berperan membentuk ketahanan masyarakat, penyelaman garis keras, serta daerah rawan terkait dengan indikasi terorisme. Forum juga melakukan pemetaan, serta mencari informasi sebanyak-banyaknya melalui intelijennya. Kegiatan sosialisasi dilakukan dalam hal pencegahan.

Beberapa alasan sehingga daerah Bali menjadi sasaran aksi terorisme sehubungan posisi Bali yang terbuka(Data Kesbanglinmas Bali):

- Memiliki pantai terbuka membentang sepanjang lebih kurang $400 \mathrm{~km}$;

- Banyak memiliki pelabuhan tradisional seperti Kedonganan, Selemadeg, Soka, Pengambengan, Pegametan, Kampung Anyar, Amed, Medewi, Kusamba, Gemicik dll;

- Sebagai daerah tujuan pariwisata;

- Masyarakat Bali yang ramah.

Sedangkan alasan umum bahwa Bali menjadi target serangan teroris adalah (Data Kesbanglinmas Bali):

- Bali merupakan daerah tujuan pariwisata paling terkenal di Indonesia;

- Banyak wisatawan asing seperti; Amerika, Australia, Inggris, Perancis, Italia dll;

- Apabila serang teroris terjadi di Bali, hal ini dengan cepat berdampak global karena dengan mudah dapat diakses melalui media internasional;

- Ketiga hal tersebut diatas memenuhi salah satu karakter terorisme yaitu Publikasi dengan cepat ke seluruh dunia.
Fungsi Kesbangpol adalah preemtif dan preventif. Preemptif dengan melakukan pembinaan, yaitu dalam hal ada indikasi serta gelagat mencurigakan disini dapat dilakukan interfensi oleh kesbang. Fungsi Preemtifkesbang dengan melakukan interaksi atau menjalin hubungan dengan desa pakraman, FKDM, FKUB, Kanwil Agama. Sementara itu fungsi secara Preventifketika telah menyinggung falsafah keamanan negara maka akan ditindak. Akan di bentuk pengawasan sifatnya adalah informasi dan kordinasi, kesbang juga telah memiliki Standar operasional tanggap darurat dalam hal ada kejadian darurat seperti aksi terorisme.

Kesbang mengadakan rapat koordinasi rutin dengan topik sesuai dengan permasalahannya termasuk dalam hal ini membahas ancaman aksi terorisme. Dengan menerima pengaduan atau laporan dari seluruh masyarakat. Fungsi Kesbang termasuk juga menjalankan tugas-tugas dari Gubernur di daerah dan menjalankan tugas-tugas sebagai wakil pemerintah pusat di wilayah serta menangani semua urusan yang tidak diselesaikan oleh instansi lain.

Kesbang juga bekerjasama dengan BPBD (Badan Penanggulangan Bencana Daerah) yang preventif dalam hal penanggulangan bencana daerah, baik bencana akibat alam ataupun akibat ulah manusia. Pasca terjadinya terorisme kesbang berperan dalam hal koordinasi dan mengumpulkan informasi seperti mencari informasi mengenai jumlah korban, mengkoordinasikan agar semua sarana prasarana ada dan proses penanganan berjalan dengan baik.

Mengenai pembiayaan dari kegiatan Kesbang anggaran menjadi tanggungan Gubernur dalam hal Pemda yang memiliki kewenangan bugeting bertanggung jawab. Namun dalam pelaksanaan tugasnya, Kesbang memiliki kendala atau hambatan antara lain masih minimnya biaya intelijent dan pemanfaatan jaringan serta perlu ditangkatkannya sumber daya manusia (SDM) baik dari kualitas maupun kuantitas.

Berkaitan dengan tugas preventif bentuk pengawasan sifatnya informasi dan kordinasi, Kesbang telah melakukan pemetaan daerah di 
Provinsi Bali yang rawan penyelaman teroris antara lain:

- Di Kabupaten Buleleng; Desa Sangsit Kec Sawan, Desa Pengayaman, Desa Pengastulan Seririt, Desa Celukan Bawang Kecamatan Gerogak, Desa Patas Kec Gerogak, Desa Pengametan, Desa Sedang Pasir, Desa Sumber Kelampok.

- Di Kabupaten Jembrana; Desa PebuahanMalaya, Desa Tegal Badeng, Desa Pengambengan.

- Di Kabupaten Gianyar; Tempat Kos sekitar Terminal Ubud, Semebaung Desa Bedulu, Lingkaran Pas Dalem.

- Di Kabupaten Tabanan; Desa Candi Kuning.

- Di Kabupaten Karangasem; Desa Kecicang, Desa Ujung, Desa Dangin Kebon, Desa Bukit Tabuan, Desa Tanah Lengis, Kp Buitan, Manggis.

- Di Kabupaten Klungkung; Kp Muslim Desa Gelgel, Desa Lebah, Desa Kusamba, Nusa Penida

- Di Kabupaten Badung; Nusa Dua, Tanjung Benoa, Jimbaran, Kp Bugis Tuban, Seminyak, Kerobokan.

- Di Kota Denpasar; Tempat Kos dan penginapan di Ubung, Kampung Jawa J1 A. Yani. J1 Gatsu Barat, Perum Monang-Maning, Kampung Muslim Kepaon.

Dalam hal ada potensi ancaman radikalisme atau aksi teroris maka standar operasional prosedur Kesbangpolinmas dengan institusiinstitusi terkait lainnya yaitu;

a) Jika ada potensi ancaman radikalisme atau aksi teroris maka data akan dikaji dalam Pusat Informasi Intelijen, maka yang menjadi subjek adalah institusi; Binda, Polda, Kodam, Korem, Lanal, Lanud, Kejaksaan Tinggi, Bea Cukai, Kesbangpol, Imigrasi, Satgas Badan Intelijen Strategsi (BAIS) TNI, FKDM, FKUB, FKPT, Masyarakat. Sedangkan objeknya adalah; Pers Prominent, Simpul massa, jejaring/teroris, masyarakat Bali.

b) Data setelah dikelola oleh Pusat Informasi Intelijen kemudian diklasifikasikan dalam 3 kelompok yaitu;
-Pertama; membentuk opini dengan sosialisasi sebagai langkah antisipasi, tanggap dini dan cegah dini;

-Kedua; melakukan istilahnya netralisasi, kenalisasi dan reduksi;

-Ketiga; pelaporan secara cepat, mengarah kepada tindakan oleh Polda dan institusi terkait lainnya.

Dengan menciptakan situasi kondusifmaka akan tercapai masyarakat Bali yang aman, nyaman dan tenteram.

\section{Forum Koordinasi Pencegahan Terorisme (FKPT)}

Visi Forum Koordinasi Pencegahan Terorisme(FKPT) Provinsi Bali yaitu terwujudnya Provinsi Bali bebas dari terorisme 2020, dengan misi antara lain Internalisasi nilai kearifan lokal berdasarkan pancasila dan UUD 1945 bagi terwujudnya impian Bali Bebas dari Terorisme.

FKPT merupakan kepanjangan tangan dari Badan Nasional Penanggulangan Terorisme (BNPT) yang bertugas mengkoordinasikan dengan seluruh stakeholders terkait penanggulangan terorisme, FKPT melibatkan diri dalam berbagai aktifitas pencegahan terorisme yang dilakukan lembaga terkait di wilayah masing-masing atau sebagai organisasi koordinasi yang membantu BNPT dalam sosialisasi dan upaya-upaya pencegahan terorisme di setiap wilayah provinsi.

FKPT Provinsi Bali melakukan berbagai upaya untuk mencegah aksi radikal dan terorisme muncul di Pulau Dewata. Sejumlah langkah tersebut diantaranya bersinergi dengan pemuda, pendidik, tokoh masyarakat serta tokoh agama untuk membantu aparat keamanan menangkal riak kemunculan teroris. Ketua FKPT Bali Gede Putu Jaya Suartama menjelaskan, melawan teroris bukan secara fisik saja, melainkan mencakup ideologi yang mereka bawa (http: // www.voiceofummah.net/waspadai - terorisme berniat - ubah - ideology/, diakses 30 Oktober 2016).

Perlawanan secara fisik lebih mudah dilakukan, namun tantangan berat ada pada perlawanan ideologi. Oleh karena itu, melalui 
sinergi semua komponen, masyarakat bali dan Indonesia pada umumnya harus disadarkan dan diingatkan kembali pada ideologi bangsa yakni Pancasila. Tantangan berat melawan teroris bukan hanya pada perlawanan fisik, melainkan ideologi yang mereka bawa. Ketua Forum Koordinasi Pencegahan Terorisme Gede Putu Jaya Suartama mengatakan, melalui Program Bali Mandara yang dilaksanakan Pemprov Bali dapat membentuk karakter bangsa. Misalnya program jaminan kesehatan, peningkatan pelayanan publik hingga program pengentasan kemiskinan yang intens dilaksanakan dapat mengurangi keinginan masyarakat memberontak terhadap pemerintah, serta mencoba berbuat hal-hal diluar keyakinan ideologi Pancasila.

Pemerintah Kota (Pemkot) Denpasar dan Bali pada umumnya, mulai membentuk satgassatgas khusus anti teror untuk melakukan pencegahan sejak dini maupun mengatasi aksi terorisme dalam berbagai bentuk dan skala aksi mereka. Menghadapi aksi terorisme dengan kekerasan dan ketegasan hukum pun tidak serta merta menghentikan tumbuhnya bibit-bibit baru kelompok terorisme, diperlukan sinergitas antara Pemerintah, Aparat, Swasta serta Masyarakat dalam menghadapi aksi terorisme tersebut.

FKPT Provinsi sebagai mitra strategis BNPT di daerah melakukan upaya pencegahan dengan melibatkan generasi muda juga dalam kegiatan Dialog Pencegahan Terorisme bertema "Peran Aktif Generasi Muda dalam Mencegah Radikali Terorisme di Provinsi Bali" di Bedugul, Tabanan Bali (19/09/15). Generasi muda saat ini menjadi sasaran empuk bagi penyebaran paham radikal terorisme. Karena itulah kegiatan ini menjadi sangat strategis dalam membentengi Bali dari paham radikal yang menyusup di lingkungan generasi muda. Dalam kegiatan kali, FKPT Provinsi Bali menyasar 300 peserta yang terdiri dari unsur pemuda dan perempuan, Perwakilan Forum Ormas, Organisasi Kepemudaan (OKP), Pemuda Pancasila, Organisasi Kemahasiswaan, Aktivis Perempuan, Perwakilan Darmawanita Unit/Instansi dan Wanita Kader Masyarakat Perwakilan Perempuan dan Organisasi Pemuda. Melalui kegiatan ini diharapkan terciptanya gerakan bersama yang dilakukan oleh seluruh unsur generasi muda dalam mencegah paham radikal terorisme serta menjadi Bali tetap aman dan terhindar dari berbagai gangguan teror. Tentu saja, hal yang sangat penting dari kegiatan ini adalah memperoleh masukan dan rekomendasi berharga dari kalangan generasi muda untuk kebersamaan menjaga Bali dari bahaya terorisme (https: // damailahindonesiaku.com/fkpt-galang - pemuda - dan - perempuan - bentengi - bali - dari radikal - terorisme.html, diakses 1 November 2016).

\section{Forum Kerukunan Utama Beragama (FKUB)}

Menyadari akan realitas multi-kultural yang ada dan belajar dari pengalaman sejarah masa lalu serta berbagai kejadian di beberapa daerah, maka wadah kerjasama yang kemudian dikukuhkan berdasarkan Keputusan Bersama Menteri Agama dan Menteri Dalam Negeri Nomor 09 dan Nomor 08 tahun 2006 Tentang Pedoman Pelaksanaan Tugas Kepala Daerah / Wakil Kepala Daerah dalam Pemeliharaan Kerukunan Umat Beragama, Pemberdayaan Forum Kerukunan Umat Beragama, dan Pendirian Rumah Ibadat, menjadi sangat penting untuk direalisasikan di daerah, dalam bentuk Forum Kerukunan umat Beragama atau FKUB.

Sebagai organisasi kemasyarakatan yang berbasis pada pemuliaan nilai-nilai agama, FKUB memiliki peran dan fungsi yang sangat strategis dalam berperan serta membangun daerah masingmasing ditengah krisis multidimensional yang tengah terjadi. Dua peran yang paralel yang dapat dilakukan oleh Forum Kerukunan Umat Beragama (http: //www.irwanlaw.com/ forum - kerukunan - umat - beragama / peranan - fkub - dalam memelihara-dan-memantapkan-kerukunanumat - beragama - di - kabupaten - tabanan denpasar - bali, diakses 28 Agustus 2016.):

(1) Forum hendaknya dapat menjadi jembatan penghubung di-internal umat masing-masing. Artinya, masing-masing agama secara vertikal memiliki keyakinan, cara, etika, susila yang dimiliki dan bersifat hakiki. Hal ini merupakan 
pembeda antara agama yang satu dengan yang lainnya yang harus dihormati. Oleh karena itu FKUB melalui perwakilan dimasing-masing agama harus dapat menularkan kerukunan diinternal umat, dan menjaga aspek sakralisasi pelaksanaan tradisi keberagamaan masingmasing dengan tetap berpegang pada kaidah agama.

(2) Secara horizontal, disamping intern, maka dalam perspektif sosiologi agama, hubungan yang bersifat sosial dengan umat beragama lainnya perlu dijaga dan dikembangkan.

Dalam konteks inilah FKUB dapat menjalankan peran dan fungsinya sebagai:

- Sebagai wahana komunikasi, interaksi antara satu dengan yang lainnya dalam memberikan informasi terhadap tafsir agama masingmasing, sehingga tercipta suasana saling memahami dan saling menghormati;

- Sebagai wahana mediasi setiap persoalan yang mengarah pada terjadinya konflik baik yang bersifat laten maupun manifest;

- Sebagai media harmonisasi hubungan satu dengan yang lain dalam mengkomunikasikan pelaksanaan kegiatan-kegiatan keagamaan;

- Melakukan sosialisasi kepada masing-masing umat beragama; agar dalam kehidupan sosial tidak bersifat eksklusif sehingga dapat terbangun kohesi sosial dikalangan umat beragama;

- Membantu pemerintah daerah dalam mensukseskan program-program pembangunan; - Bersama-sama pemerintah dan aparat kemanan ikut menjaga iklim sosial dan politik yang kondusif; dan

- Tentunya banyak hal lagi yang dapat dikerjakan dengan selalu bersinergi dengan kekuatan-kekuatan sosial yang ada di daerah.

Ketua FKUB (Forum Kerukunan Umat Beragama) Bali, Ida Pengelingsir Agung Putra Sukahet mengatakan, Bali sudah menjadi ikon nasional dalam menjaga kerukunan umat beragama. Beliau mengatakan, dalam mempertahankan hal tersebut, Bali memiliki identitas filosofis, menguatkan Pancasila, Menyame Braya, Tat Twam Asi. Semua jalan yang ditempuh pada Tuhan itu semua jalan Tuhan, 52 bahkan diciptakan oleh Tuhan, semua agama sangat baik, sempurna bahkan sebagai agama, cuma manusia harus memilih satu, karena manusia tidak mampu menjalankan semuanya. Bangsa Indonesia itu orang komunal, pasti senang kebersamaan, kerukunan, gotong royong, kumpulkumpul, Jadi jika ada yang tidak senang luhur, menurutnya sudah keluar dari identitas orang Bali, orang Jawa, orang Indonesia. Ida Pengelingsir Agung Putra Sukahet menekankan, konflik antar agama itu pasti akan cepat terselesaikan ketika konflik dilaksanakan musyawarah (http : // bali.tribunnews.com / 2015 / 09 / 29 / ketua fkub-kita-jaga-agar-isu-isu-agamatidak-dipakai-isu-politik, diakses 29 Agustus 2016).

Aksi terorisme adalah yang utama tidak mengenal batas agama, dan negara. Munculnya terorisme dapat dimana saja, seperti: IRA di Irlandia Utara, Aum Shinrikyo di Jepang, Ekstremisme Sikh di India, The Army of God di Amerika Serikat, Kach and Khane Chai di Israel, ISIS di Timur Tengah, dan sebagainya.

Yang rentan paham terorisme, yaitu Orang/ pribadi yang bingung dan labil, merasa tak berharga, tidak (bisa) kritis, tertutup (di luar kelompoknya), tak bisa toleran (terhadap kelompok lain).

Ada unsur agama memang disalahgunakan, karena tidak ada agama yang mengajarkan untuk menjadi terorisme. Kata jihad salah satu yang disalahgunakan oleh teroris. Sebagaian besar kita juga tidak paham tentang istilah jihad. Dulu pernah ada resolusi jihad tahun 45. Jika pandangan kita mengenai jihad tidak pas, maka patut diragukan jangan sampai menggunakan pemahaman mengenai jihad seperti teroris. Mari kita pahami, dalam terorisme ada penyalahgunaan agama untuk pembenaran.

Pola Perekrutan Teroris antara lain Pendekatan individu, Penyamaan persepsi mengenai siapa atau apa yang dimusuhi dan Pengelompokan secara tertutup / eksklusif.

Menangkal Penyebaran Faham Radikal dan Terorisme dilakukan dengan cara; menebarkan sikap inklusif, merangkul, terbuka akan cara pandang yg berbeda, toleran, menghormati 
perasaan dan kebutuhan orang lain, merasa aman di luar kelompoknya.

Langkah yang bisa dilakukan sebagai ciri Bangsa yang tangguh, memiliki daya saing, daya tanding, menang terhadap yang lebih besar yaitu menjaga kedaulatan negara, kelestarian bumi / tanah-airnya, menjaga keamanan \& kesucian wihara/pura gereja, kanisah, dan masjid, menamkan jiwa agama Rahmat lil 'alamin, Kasih, Tat Wam Asi, Ummatan wasathan, tolak penyesatan yang sejajarkan jihad dengan terorisme, dan bangun hidup bertetangga baik.

Diharapkan peran Pemuka Agama, Peran Pengurus Masjid, Pura,Gereja, Wihara, dan Kelenteng

- Pemadu potensi umat, pusat bina umat, jamaah, jemaat.

- Pemangku sentra aktivitas keagamaan dan kebudayaan

- Pengelola pusat pembinaan spiritualitas generasi penerus.

Para pengurus memiliki kemampuan untuk menyusun kajian-kajian, dharma wacana, taqlih arahnya mewujudkan persatuan dan kesatuan bangsa. Istihad mengambil keputusan dengan berbagai pertimbangan dengan msusyawarah. Jiwa Keagamaan dalam Kenegaraan, Mewujudkan persatuan/ kesatuan umat, selesaikan beda pendapat / ijtihad dengan musyawarah (Ikut) menjaga kedaulatan negara dan larangan agressi, utamakan damai antar bangsa dan kabilah/suku bangsa.

\section{Perspektif Majelis Utama Desa Pakraman (MUDP)}

Majelis Desa Pakraman (MDP) Provinsi Bali sebagai wadah tunggal desa pakraman di Bali yang beranggotakan seluruh desa pakraman di Bali. MDP terbentuk dengan dasar hukum Peraturan Daerah Provinsi Bali No 3 Tahun 2001 tentang Desa Pakraman, yang diubah dengan Perda Provinsi Bali No 3 Tahun 2003 tentang Desa Pakraman.

Desa Pakraman dan Majelis Desa Pakraman (MDP) yang berjenjang di tingkat Majelis Alitan Desa Pakraman (MADP) di Kecamatan, Majelis Madya Desa Pakraman
(MMDP) di Kabupaten/Kota, sampai Majelis Umat Desa Pakraman (MUDP) di tingkat Provinsi Bali adalah satu kesatuan sistem dalam tubuh sistem adat Bali sebagaimana disebutkan dalam Pasal 14 Perda Provinsi Bali No 3 tahun 2001.

Pembentukan MDP memiliki visi dan misi yang dituangkan dalam Visi MDP Bali adalah terwujudnya persatuan Krama Desa Pakraman yang harmonis dan terjaganya adat dan sosial budaya Bali yang dilandasi agama Hindu. Sedangkan Misi dari MDP adalah:

a) Mewujudkan persatuan dan kesatuan Desa Pakraman;

b) Menciptakan Kasukertaan di Bali;

c) Mengayomi adat dan sosial budaya Bali;

d) Meningkatkan mutu Krama Desa Pakraman;

e) Melestarikan lingkungan dan tanah Bali.

MDP juga memiliki tugas dan wewenang yang diamanatkan dalam Pasal 16 Perda No 3 Tahun 2001, sebagai berikut:

a) Mengayomi desa adat;

b) Memberikan saran, usul, dan pendapat kepada berbagai pihak baik perorangan, kelompok/ lembaga, maupun pemerintah tentang masalahmasalah adat;

c) Melaksanakan setiap keputusan-keputusan paruman dengan aturan-aturan yang ditetapkan;

d) Membantu penyuratan awig-awig;

e) Melaksanakan penyuluhan adat-istiadat secara menyeluruh

Sedangkan untuk kewenangan MDP adalah:

a) Memusyawarahkan berbagai hal yang menyangkut masalah-masalah adat dan agama untuk kepentingan Desa Pakraman;

b) Sebagai penengah dalam kasus-kasus adat yang tidak dapat diselesaikan pada tingkat desa;

c) Membantu penyelenggaraan upacara keagamaan di kecamatan, di kabupaten/kota dan provinsi;

Kondisi umat beragama di Bali tetap harmonis, aman dan damai, ditingkat pimpinan selalu ada dialog yang hasilnya disosialisasikan ke bawah. Umat beragama di Bali mempunyai budaya yang mau menyesuaikan diri. Isu agama adalah paling sensitif dan kerukunan selalu dinamis, 
sehingga harus ikut berbudaya Bali yang mengedepakan dialog. Masyarakat adat yaitu khususnya warga beragama hindu terbina melalui Desa Pakraman. Adat sebagai pendukung implementasi ajaran Hindu.

Desa Pakraman otonomi maka untuk harmoninya maka dibentuk Majelis: MADP: Alit, MMDP: Madya, MUDP: Utama. Sifat Majelis, adalah konsultatif dan koordinatif, jika ada persoalan terjadi maka secara berjenjang penanganannya. Terkait terorisme, menyangkut kewaspadaan melalui FKUB dan Pemerintah (Kesbangpol), bentuk pencegahan dengan intensifkan penulisan awig awig. Awig awig sifatnya permanen tidak harus sering dirubah walaupun kondisi berubah (merupakan sebagai undangundangnya) sedangkan Pararem sifatnya berubahrubah seperti penjelasannya. Jenis Pararem sendiri yaitu:

a) Pararem Penjelasan Awig-awig

b) Pararem Pengelih, apapun peristiwa yang mau ditangani

c) Pararem Pemutus Wicara, menjadi yurisprudensi

Sehingga terkait kebijakan pencegahan salahsatunya terkait terorisme melalui Pararem pengelih yaitu menentukan rencana pencegahan kedepannya.

Namun dalam pelaksanaan pencegahan kejahatan terutama terkait dengan tindak pidana terorisme masih menghadapi beberapa kendala dan hambatan antara lain yaitu:

a) Berbagai lembaga, organisasi, forum, LSM di masyarakat yang tidak semua kegiatan terkoordinasi di desa Pakraman atau jalan sendiri-sendiri;

b) Ormas-ormas yang masuk desa Pakraman yang mengatur pecalang, sementara itu pecalang berada langsung dibawah MUDP hanya saja mempunyai tugas otonomi daerahnya;

c) Keluguan masyarakat tradisional;

d) Sarana dan prasarana dan dana operasional pembinaan MUDP belum memadai, yang dibantu langsung adalah desa pakraman, di Majelis masih kesulitan dalam pembiayaan.

\section{TABELSINERGISITAS KEBIJAKAN DAN STRATEGI PENCEGAHAN TINDAK PIDANA TERORISME DI PROVINSI BALI}

\begin{tabular}{|c|c|c|c|}
\hline Lembaga & $\begin{array}{c}\text { Peran terkait } \\
\text { Pencegahan } \\
\text { Terorisme }\end{array}$ & Kendala & Keterangan \\
\hline $\begin{array}{c}\text { Polda Bali } \\
\text { (Unit Anti } \\
\text { Teror, Tim } \\
\text { Media Sosial, } \\
\text { Tim } \\
\text { Deradikalisasi } \\
\text { ) }\end{array}$ & $\begin{array}{l}\text { 1. Pemetaan } \\
\text { Imapping } \\
\text { daerah rawan } \\
\text { (dilewati/diting } \\
\text { gali) } \\
\text { 2. Upaya Deteksi } \\
\text { Dini dan } \\
\text { Cegah Dini } \\
\text { 3. Razia berlaka } \\
\text { bersama } \\
\text { 4. Deteksi melalui } \\
\text { media sosial } \\
\text { (website) } \\
\text { 5. Pengawasan } \\
\text { 'sel mati' } \\
\text { 6. Siaga di tempat } \\
\text { vital } \\
\text { 7. Upaya } \\
\text { Deradikalisasi }\end{array}$ & 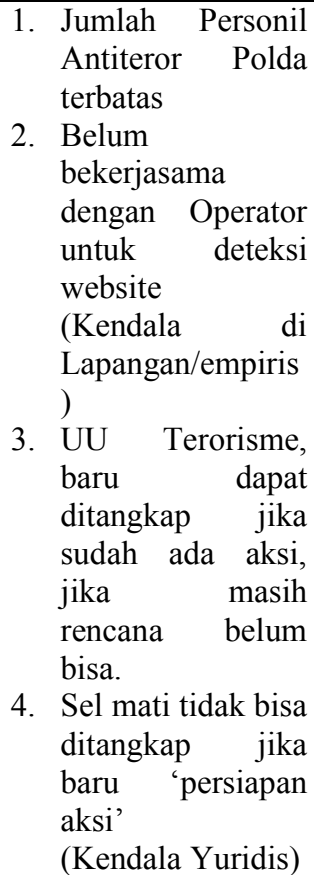 & $\begin{array}{l}\text { Melibatkan } \\
\text { Tokoh agama, } \\
\text { Masyarakat } \\
\text { (termasuk } \\
\text { Kelompok } \\
\text { Nelayan), } \\
\text { Babinkamtibnas } \\
\text {, Polres, Polair, } \\
\text { TNI, Aparat } \\
\text { Desa, Pecalang, } \\
\text { Kominda, } \\
\text { FKUB, MUDP, } \\
\text { BNPT/FKPT } \\
\text { (upaya } \\
\text { deradikalisasi = } \\
\text { gandeng tokoh } \\
\text { agama, } \\
\text { masyarakat \& } \\
\text { Depag), } \\
\text { Kesbangpol, } \\
\text { LPSK. }\end{array}$ \\
\hline
\end{tabular}




\begin{tabular}{|c|c|c|c|}
\hline $\begin{array}{l}\text { Kesbangpol } \\
\text { (Pelaksana } \\
\text { Koordinasi } \\
\text { Intelijen, } \\
\text { FKDM) }\end{array}$ & 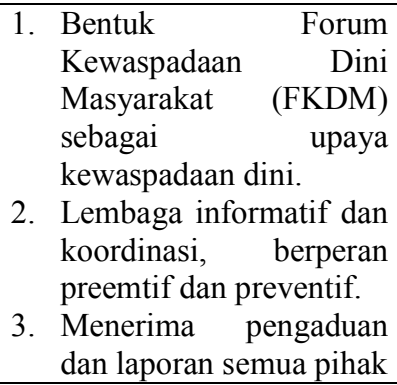 & $\begin{array}{ll}\text { 1. } & \text { Minim } \\
\text { pembiayaan } \\
\text { kegiatan yang } \\
\text { cukup beragam } \\
\text { 2. Perlunya } \\
\text { peningkatan } \\
\text { SDM (kuantitas } \\
\text { maupun kualitas) }\end{array}$ & $\begin{array}{l}\text { Melibatkan Pemerintah } \\
\text { Daerah (gubernur), FKDM, } \\
\text { BPBD, Polda, Badan } \\
\text { Intelijen Daerah, TNI, } \\
\text { Kemenkum HAM Bali, } \\
\text { tokoh masyarakat, tokoh } \\
\text { agama, praktisi/akademisi } \\
\text { hukum, unsur pemuda, } \\
\text { FKUB, Kementrian Agama, } \\
\text { dan Kominda. }\end{array}$ \\
\hline $\begin{array}{c}\text { FKPT } \\
\text { /perwakilan } \\
\text { BNPT } \\
\text { (Akademisi) }\end{array}$ & $\begin{array}{l}\text { 1. Sifatnya koordinatif } \\
\text { pencegahan terorisme } \\
\text { 2. Berbagai upaya } \\
\text { pencegahan melalui } \\
\text { dialog, seminar anti } \\
\text { teroris kepada berbagai } \\
\text { lapisan masyarakat } \\
\text { 3. Melakukan penelitian } \\
\text { dan pengkajian gejala } \\
\text { dan potensi terjadinya } \\
\text { radikal terorisme serta } \\
\text { mengembangkan model- } \\
\text { model pencegahannya } \\
\text { 4. Upaya Deradikalisasi }\end{array}$ & $\begin{array}{l}\text { Kewenagannya yang } \\
\text { terbatas pada } \\
\text { koordinatif }\end{array}$ & $\begin{array}{l}\text { Kepolisian, BNPT, BPBD, } \\
\text { Forum Pecalang, Akademisi, } \\
\text { seluruh pemerintah daerah } \\
\text { terkait dan masyarakat serta } \\
\text { organisasi dalam } \\
\text { masyarakat. }\end{array}$ \\
\hline FKUB & $\begin{array}{l}\text { 1. Organisasi masyarakat } \\
\text { berbasis pemuliaan } \\
\text { agama sebagai wadah } \\
\text { kerjasama antar umat } \\
\text { beragama. } \\
\text { 2. Jembatan penghubung } \\
\text { umat beragama }\end{array}$ & & $\begin{array}{l}\text { Berkoordinasi dengan } \\
\text { Kepolisian, Kesbang, } \\
\text { Seluruh Tokoh Agama } \\
\text { Indonesia, MUDP }\end{array}$ \\
\hline MUDP & $\begin{array}{l}\text { 1. Pencegahan melalui } \\
\text { Desa Pakraman } \\
\text { 2. Bersifat Konsultatif dan } \\
\text { Koordinatif } \\
\text { 3. Bentuk pencegahan } \\
\text { dengan intensifkan } \\
\text { dalam penulisan Awig- } \\
\text { awig } \\
\text { 4. Penguatan pecalang } \\
\text { sebagai lembaga } \\
\text { pengamanan dan } \\
\text { peratahanan masyarakat }\end{array}$ & 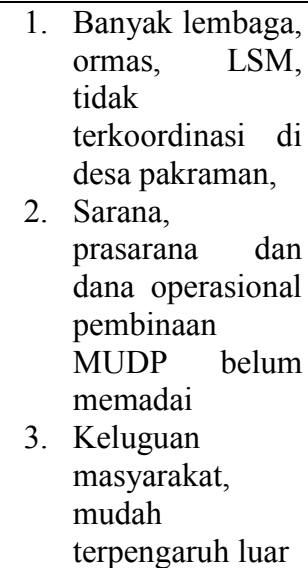 & $\begin{array}{ll}\text { Berkoordinasi } & \text { dengan } \\
\text { Kepolisian, } & \text { FKUB, } \\
\text { Kesbangpol, Pemda, FKDM, } & \\
\text { TNI } & \end{array}$ \\
\hline
\end{tabular}

\section{PENUTUP}

\section{A. Simpulan}

1. Terorisme merupakan permasalahan seluruh Bangsa Indonesia bahkan telah menjadi pusat perhatian dunia dalam pencegahan dan pemberantasannya. Di Provinsi Bali pencegahan yang bersinergi dilakukan Polda Bali, Kesbangpolinmas Bali, FKPT, dan Tokoh-tokoh Masyarakat dan Agama di Bali masing-masing instansi / organisasi / lembaga / individu dan telah melaksanakan kewajiban sesuai tupoksi dengan efektif terkait strategi dan kebijakan pencegahan terorisme.

2. Serta masing-masing instansi / organisasi / lembaga / individu telah mengupayakan mensinergikan kebijakan dan strategi pencegahan terorisme. Hanya terdapat 
beberapa kendala mulai dari pendanaan, sarana-prasarana, kualitas-kuantitas SDM sampai dengan kendala terkait peraturan perundang-undangan.

\section{B. Rekomendasi}

1. Dengan mengidentifikasi beberapa permasalahan, hingga menemukan solusi terbaik untuk lebih efektifnya pencegahan aksi terorisme secara bersinergi dan berkelanjutan, diantaranya yaitu meningkatkan sarana dan prasarana serta pendanaan dalam hal upaya pencegahan masing-masing pihak, sampai dengan menambah personil serta meningkatan kualitas dari SDM melalui pelatihan terkait strategi dan kebijakan pencegahan aksi terorisme.

2) Pemerintah diharapakan lebih memotivasi agar semua komponen perkuat nasionalisme kebangsaan sesuai UUD NRI 1945 dan pancasila dan NKRI. Perlu penyesuaian dalam undang-undang terorisme yang ada sehingga mengakomodasi kendala Kepolisian untuk dapat melakukan pencegahan lebih efektif yaitu dalam hal mengakomodasi ketentuan penangkapan terduga teroris walaupun masih dalam tahap persiapan bahkan tahap perencanaan aksinya. Dengan demikian penanggulangan secara preventif dirasakan lebih efektif dan memperkecil ruang gerak aksi pelaku. Serta kepada masyarakat agar taati agama, hidup bernegara yang seimbang dharma agama dan dharma negara

\section{DAFTAR PUSTAKA}

Buku

Agus SB, 2014, Darurat Terorisme, Kebijakan Pencegahan, Perlindungan dan Deradikalisasi, Daulat Press, Jakarta.

Arif, Barda Nawawi, 2010, Kebijakan Hukum Pidana; Perkembangan Penyusunan Konsep KUHP Baru, Kencana, Jakarta.

Kuntjaraningrat, 1999, Kebudayaan, Metalitet \& Pembangunan, Gramedia, Jakarta.

Soemitro, Rony Hanitijo, 1998, Metode Penelitian Hukum dan Jurimetri, Ghalia Indonesia, Jakarta.
Wahid, Abdul, dkk, 2004, Kejahatan Terorisme Perspektif Agama, HAM dan Hukum, PT.Refika Aditama, Bandung.

Wehmeier, Sally, dkk., 2000, Oxford Advanced Learner's Dictionary of Current English, Oxford University Press, Amerika Serikat.

\section{Website}

https://id.wikipedia.org/ Serangan Jakarta 2016, diakses 16 januari 2016.

http://www.merdeka.com/peristiwa/, Biasa ngebom, mungkinkan teroris teror polisi dengan racun sianida?, diakses 20 februari 2016.

http://www.voiceofummah.net/waspadaiterorisme-berniat-ubah-ideologi/,diakses 30 Oktober 2016.

https://damailahindonesiaku.com/fkpt-galangpemuda-dan-perempuan-bentengi-balidari-radikal-terorisme.html, diakses 1 November 2016.

http://www.irwanlaw.com/forum-kerukunanumat-beragama/peranan-fkub-dalammemelihara-dan-memantapkankerukunan-umat-beragama-di-kabupatentabanan-denpasar-bali, diakses 28 Agustus 2016.

http://bali.tribunnews.com/2015/09/29/ketuafkub-kita-jaga-agar-isu-isu-agamatidak-dipakai-isu-politik, diakses 29 Agustus 2016.

\section{Narasumber}

Komisaris Polisi Tri Joko, Kanit 4 Unit Anti Teror, Kompol Agung Budiarta Kanit 2 Sub Dit 4 Direktorat Intelkam dan AKP Suryadi, Panit Unit 4 Polda Bali.

Prof.Dr. Rai Setiabudhi, SH, MS, Pengurus Forum Komunikasi Penaggulangan Terorisme Provinsi Bali.

I Gede Agus Arjawa Tangkas, Pelaksana Koordinasi Intelijen Kesatuan Bangsa dan Politik serta Perlindungan Masyarakat.

H.Roichan Muchlis, Wakil Sekertaris Forum Kerukunan Umat Beragama Provinsi Bali. Drs I Gusti Made Ngurah, Msi, Wakil Bendesa Agung Majelis Utama Desa Pakraman (MUDP). 